УДК 378.014.543(477)

Тоцька Олеся,

кандидат економічних наук, доцент,

Східноєвропейський національний університет імені Лесі Українки,

кафедра фінансів,

м. Луцьк; ORCID ID 0000-0003-4748-2134

e-mail: Totska.Olesia@eenu.edu.ua

https://doi.org/10.29038/2411-4014-2020-04-80-88

\title{
МЕХАНІЗМ ФІНАНСОВО-ІНВЕСТИЦІЙНОГО ЗАБЕЗПЕЧЕННЯ РОЗВИТКУ ВИЩОЇ ОСВІТИ УКРАЇНИ В КОНТЕКСТІ ФУНКЦОНУВАННЯ ЄПВО
}

У статті здійснено аналіз вітчизняних авторефератів дисертацій, присвячених дослідженню фінансової сфери вищої освіти. Проаналізовано показники сателітного рахунку освіти в Україні за 2018 р. за фінансуючими організаціями (фінансовими агентами), провайдерами (постачальниками послуг) та функціями освіти. Сформовано механізм фінансово-інвестиційного забезпечення розвитку вищої освіти України в контексті функціонування Свропейського простору вищої освіти (СПВО), який містить фінансових агентів, інструменти та відповідні заходи на макро-, мезо- й мікрорівнях. Наведено перелік документів ЄПВО. Сформовано рекомендації щодо вдосконалення фінансово-інвестиційного забезпечення розвитку вищої освіти в частині доходів і видатків. Визначено перспективи подальших досліджень.

Ключові слова: механізм, фінансово-інвестиційне забезпечення, фінансові агенти, провайдери, вища освіта, Європейський простір вищої освіти.

Тоцкая Олеся, кандидат экономических наук, доцент, Восточноевропейский национальный университет имени Леси Украинки, кафедра финансов, г. Луцк

\section{МЕХАНИЗМ ФИНАНСОВО-ИНВЕСТИЦИОННОГО ОБЕСПЕЧЕНИЯ РАЗВИТИЯ ВЫСШЕГО ОБРАЗОВАНИЯ УКРАИНЫ В КОНТЕКСТЕ ФУНКЦИОНИРОВАНИЯ EПBО}

В статье проведен анализ отечественных авторефератов диссертаций, посвященных исследованию финансовой сферы высшего образования. Проанализированы показатели сателлитного счета образования в Украине за 2018 г. по финансирующим организациям (финансовым агентам), провайдерам (поставщикам услуг) и функциям образования. Сформирован механизм финансово-инвестиционного обеспечения развития высшего образования Украины в контексте функционирования Европейского пространства высшего образования (ЕПВО), который содержит финансовых агентов, инструменты и соответствующие меры на макро-, мезо- и микроуровнях. Приведен перечень документов ЕПВО. Сформированы рекомендации по усовершенствованию финансово-инвестиционного обеспечения развития высшего образования в части доходов и расходов. Определены перспективы дальнейших исследований.

Ключевые слова: механизм, финансово-инвестиционное обеспечение, финансовые агенты, провайдеры, высшее образование, Европейское пространство высшего образования.

Totska Olesia, PhD in Economics, Associate Professor, Lesya Ukrainka Eastern European National University, Department of Finance, Lutsk

\author{
MECHANISM OF FINANCIAL AND INVESTMENT SUPPORT FOR THE \\ DEVELOPMENT OF HIGHER EDUCATION OF UKRAINE IN THE CONTEXT \\ OF THE FUNCTIONING OF THE EHEA
}


Introduction. The development of education in general and higher education in particular provides funding from the budgets of various levels. According to the law, the state provides allocations for education in the amount of not less than seven percent of GDP from the state, local budgets and other sources of funding not prohibited by law. The purpose of the article is to to form a mechanism of financial and investment support for the development of higher education in Ukraine in the context of the functioning of the European Higher Education Area (EHEA). Results. In 2018, the contributions of the Ministry of Education and Science of Ukraine (44,77\%), households $(26,66 \%)$ and regional budgets/local government $(12,31 \%)$ were the most significant in general expenditures on higher education. Contributions from other financial agents were less than $10 \%$ of the total. The costs of higher education providers were as follows: services in the field of education $-91,47 \%$; secondary activities within educational institutions 3,67\%; secondary activities related to education $-4,85 \%$. The formed mechanism of financial and investment support for the development of higher education in Ukraine in the context of the EHEA includes financial agents (Central Government, regional budgets/local government, non-governmental sector), tools and relevant measures at the macro-, meso- and microlevels. Conclusions. Recommendations for improving the financial and investment support for the development of higher education in terms of income (diversification of sources of funding for higher education institutions (HEIs) with increasing the share of regional and local budgets; intensification of work with various funds, centers, donors and philanthropists; revival of own investment activity; diversification of products (goods, works, services)) and expenditures (reduction in the total share of consumption expenditures that ensure the current functioning of the HEIs; increase in the total share of development expenditures for financial support of scientific, investment and innovation activities of the HEIs) are formed.

Keywords: mechanism, financial and investment support, financial agents, providers, higher education, European Higher Education Area.

Постановка проблеми та їі значення. Розвиток освіти загалом і вищої зокрема забезпечує фінансування з бюджетів різних рівнів. Так, згідно ст. 78 «Фінансування системи освіти» ЗУ «Про освіту», держава забезпечує асигнування на освіту в розмірі не менше ніж сім відсотків ВВП за рахунок коштів державного, місцевих бюджетів та інших джерел фінансування, не заборонених законодавством. Фінансування вищої і післядипломної освіти здійснюється за рахунок коштів державного, місцевого бюджетів та інших джерел, не заборонених законодавством. Заклади освіти мають право отримувати фінансування різних видів та 3 різних джерел, не заборонених законодавством. Державні i комунальні заклади освіти мають право розміщувати власні надходження на поточних рахунках, тимчасово вільні кошти - на депозитах у банках державного сектору, а також самостійно розпоряджатися надходженнями від зазначених коштів 3 метою провадження діяльності, передбаченої установчими документами [1].

Аналіз останніх досліджень i публікацій. Фінансовій сфері вищої освіти присвятили автореферати своїх дисертаційних робіт Т. М. Боголіб, О. Ю. Буцька, М. Ванієва, В. М. Гельман, А. М. Гончаренко, О. Ю. Єрфорт, Л. І. Іщук, Т. О. Лев, В. А. Муравська, А. Г. Олексин, О. В. Тимошенко, О. Л. Шашкевич, О. В. Яришко, М. Я. Яструбський та ін. Вони дослідили фінансове забезпечення розвитку вищої освіти і науки в Україні [2]; фінансове забезпечення діяльності закладу вищої освіти (ЗВО) [3]; фінансовий механізм регулювання діяльності державних ЗВО [4]; фінансове забезпечення вищої освіти в Україні [5]; управління капіталом приватного 3ВО [6]; розвиток системи фінансового забезпечення вищої освіти в Україні [7]; формування та використання фінансових ресурсів у ЗВО [8]; здійснили синтез системи фінансового менеджменту державного 3ВО, що функціонує в умовах ринку [9]; формування механізму фінансового забезпечення аграрної вищої освіти та науки в Україні [10]; вивчили ефективність фінансування освітніх інновацій в системі вищої освіти України [11]; фінансовий механізм функціонування та розвитку системи вищої освіти в Україні [12]; оптимізацію формування й ефективність використання фінансових ресурсів 3ВО [13]; фінансове управління 3ВО I-II рівня акредитації [14]; управління фінансовими ресурсами ЗВО в умовах трансформації економіки України [15]. Однак зважаючи на приєднання України до Болонського процесу в 2005 р., вважаємо за доцільне розробити механізм фінансово-інвестиційного забезпечення розвитку вітчизняної вищої освіти, враховуючи пов'язані 3 цим реалії.

Мета і завдання статті. Метою статті є сформувати механізм фінансово-інвестиційного забезпечення розвитку вищої освіти України в контексті функціонування Свропейського простору вищої освіти (СПВО). Для їі реалізації поставлено й виконано такі завдання: 
- проаналізувати показники сателітного рахунку освіти в Україні за 2018 р. за фінансовими агентами, провайдерами та функціями освіти;

- розробити механізм фінансово-інвестиційного забезпечення розвитку вітчизняної вищої освіти на макро-, мезо- та мікрорівні;

- сформувати рекомендації щодо вдосконалення фінансово-інвестиційного забезпечення розвитку вищої освіти.

Викладення основного матеріалу та обгрунтування отриманих результатів дослідження. Аналіз показників сателітного рахунку освіти в Україні за 2018 р. почнемо з розподілу витрат на освіту за фінансуючими організаціями (фінансовими агентами) та провайдерами (постачальниками послуг). Як видно з табл. 1, найбільше коштів направлялось на вищу освіту $(28,66 \%)$, перший етап середньої освіти $(22,37 \%)$ та початкову освіту $(20,93 \%)$.

Таблиия 1

Розподіл витрат на освіту в 2018 р. за фінансуючими організаціями (фінансовими агентами) та провайдерами (постачальниками послуг) млрд грн

\begin{tabular}{|c|c|c|c|c|c|c|c|c|c|}
\hline \multirow{3}{*}{\multicolumn{2}{|c|}{ Фінансові агенти }} & \multirow{4}{*}{$\begin{array}{l}\text { Усьо- } \\
\text { го } \\
\\
189,41 \\
\end{array}$} & \multicolumn{7}{|c|}{ Провайдери } \\
\hline & & & \multirow{2}{*}{ 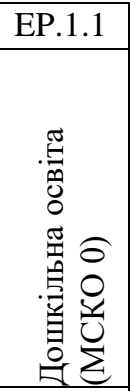 } & \multirow{2}{*}{ 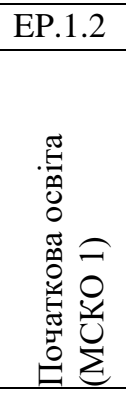 } & \multirow{2}{*}{ 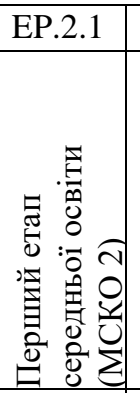 } & \multirow{2}{*}{ 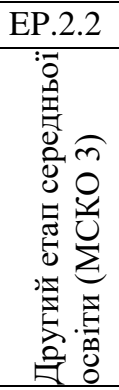 } & \multirow{2}{*}{ 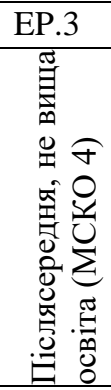 } & \multirow{2}{*}{ 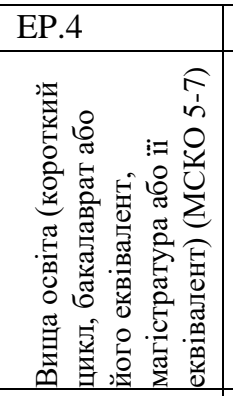 } & \multirow{2}{*}{ 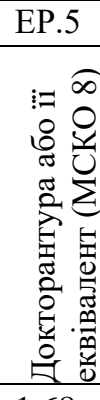 } \\
\hline & & & & & & & & & \\
\hline EF.1 & Державний сектор & & 31,79 & 43,39 & 46,38 & 11,92 & 10,00 & 44,24 & 1,68 \\
\hline EF.1.1. & Центральний уряд & 38,38 & & 0,17 & 0,18 & 0,05 & 0,28 & 36,69 & 1,00 \\
\hline EF.1.1.1 & $\begin{array}{l}\text { Міністерство освіти і } \\
\text { науки (МОН) України }\end{array}$ & 27,96 & & 0,08 & 0,08 & 0,02 & 0,28 & 27,47 & 0,03 \\
\hline EF.1.1.2 & $\begin{array}{l}\text { М-ство внутрішніх } \\
\text { справ (МВС) України }\end{array}$ & 3,06 & & & & & & 3,06 & \\
\hline EF.1.1.3 & М-во культури України & 1,28 & & 0,09 & 0,10 & 0,03 & & 1,01 & 0,05 \\
\hline EF.1.1.4 & М-во оборони України & & & & & & & & \\
\hline EF.1.1.5 & $\begin{array}{l}\text { М-во охорони здоров'я } \\
\text { України }\end{array}$ & 5,21 & & & & & & 4,79 & 0,42 \\
\hline EF.1.1.6 & $\begin{array}{l}\text { М-во соціальної } \\
\text { політики України }\end{array}$ & 0,003 & & & & & & & 0,003 \\
\hline EF.1.1.7 & $\begin{array}{l}\text { М-во аграрної політи- } \\
\text { ки та продовольства } \\
\text { України }\end{array}$ & 0,02 & & & & & & & 0,02 \\
\hline EF.1.1.8 & $\begin{array}{l}\text { М-во інфраструктури } \\
\text { України }\end{array}$ & & & & & & & & \\
\hline EF.1.1.10 & М-во фінансів України & 0,21 & & & & & & 0,20 & 0,01 \\
\hline EF.1.1.11 & $\begin{array}{l}\text { Державна фіскальна } \\
\text { служба України }\end{array}$ & & & & & & & & \\
\hline EF.1.1.12 & Інші м-ва та відомства & 0,63 & & & & & 0,004 & 0,16 & 0,46 \\
\hline EF.1.2 & $\begin{array}{l}\text { Обласні бюджети/ } \\
\text { Місцевий уряд }\end{array}$ & 151,03 & 31,79 & 43,22 & 46,20 & 11,87 & 9,72 & 7,55 & 0,68 \\
\hline EF.2 & Недержавний сектор & 24,59 & 1,28 & 1,41 & 1,50 & 0,39 & 1,16 & 17,10 & 1,77 \\
\hline EF.2.1 & $\begin{array}{l}\text { Приватні фірми та } \\
\text { корпорації }\end{array}$ & 1,44 & 0,02 & 0,01 & 0,01 & 0,003 & 0,25 & 0,74 & 0,40 \\
\hline EF.2.2 & Домашні господарства & 23,16 & 1,27 & 1,39 & 1,49 & 0,38 & 0,91 & 16,35 & 1,36 \\
\hline EF.3 & Увесь інший світ & & & & & & & & \\
\hline Усього & & 214,00 & 33,07 & 44,80 & 47,88 & 12,30 & 11,16 & 61,34 & 3,45 \\
\hline$\%$ & & 100,00 & 15,45 & 20,93 & 22,37 & 5,75 & 5,22 & 28,66 & 1,61 \\
\hline
\end{tabular}

Джерело: Сформовано автором на основі [16]. 
Витрати фінансових агентів на різноманітних провайдерів освіти було таким: Міністерство внутрішніх справ України витрачало кошти тільки на вищу освіту; Міністерство соціальної політики України й Міністерство аграрної політики та продовольства України - на докторантуру або ії еквівалент; Міністерство оборони України, Міністерство інфраструктури України, Державна фіскальна служба України не займалися фінансуванням освіти; всі інші фінансові агенти розподіляли витрати між декількома провайдерами одночасно.

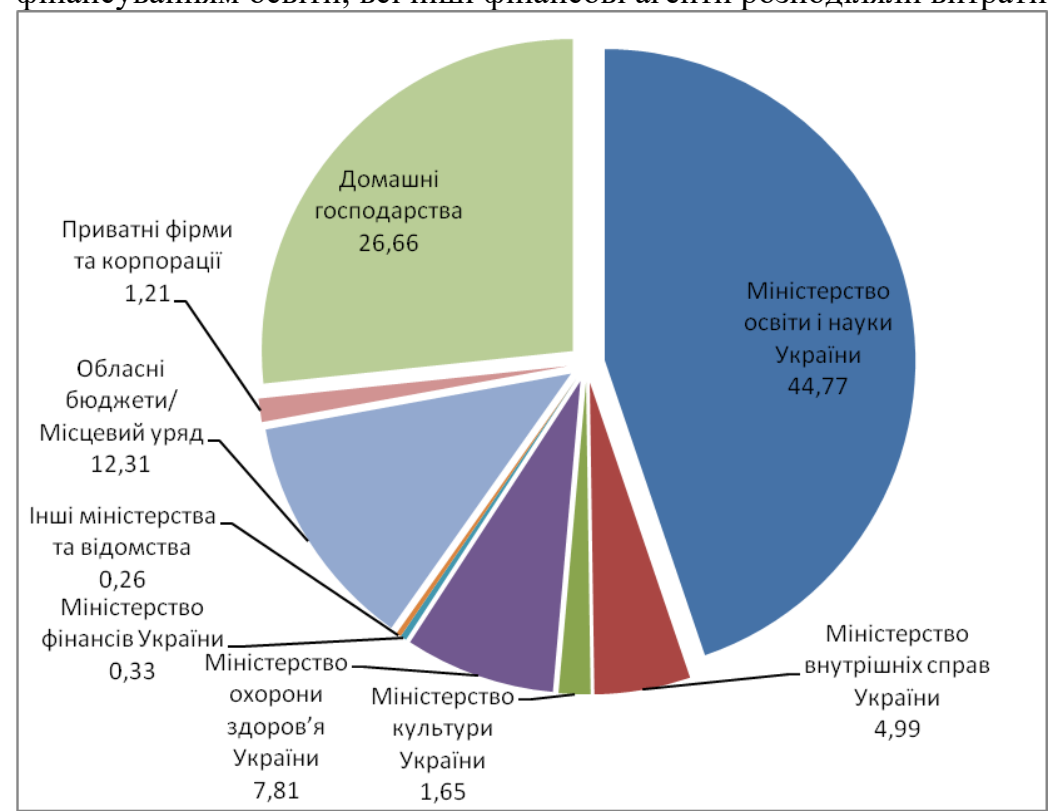

Рис. 1. Витрати на вищу освіту в 2018 р. за фінансовими агентами, \%

Джерело: Сформовано автором на основі табл. 1.

У загальних витратах на вищу освіту найвагомішими були внески Міністерства освіти і науки

України (44,77 \%), домашніх господарств (26,66 \%) і обласних бюджетів/місцевого уряду (12,31 \%).

Внески інших фінансових агентів становили менше 10 \% від загальної суми. Це показано на рис. 1.

Таблиця 2

Розподіл витрат на освіту в 2018 р. за провайдерами (постачальниками послуг) і функціями освіти, млрд грн1

\begin{tabular}{|c|c|c|c|c|c|c|c|c|c|c|c|}
\hline \multirow[b]{2}{*}{ Провайдери } & \multirow[b]{2}{*}{ Усьо-го } & \multicolumn{10}{|c|}{ Функції } \\
\hline & & 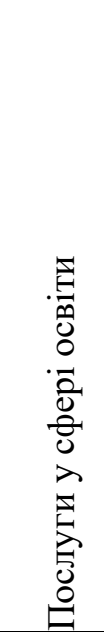 & 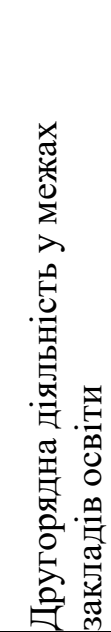 & 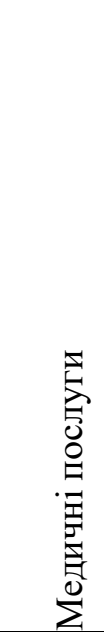 & 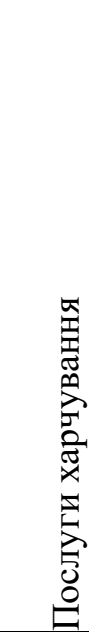 & 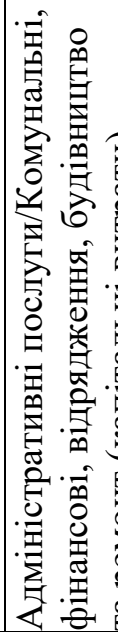 & 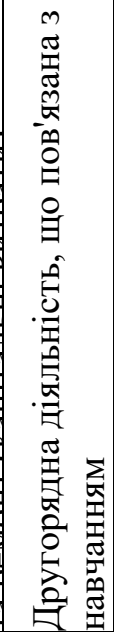 & 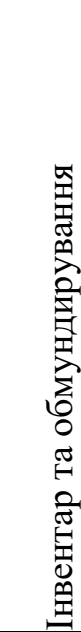 & 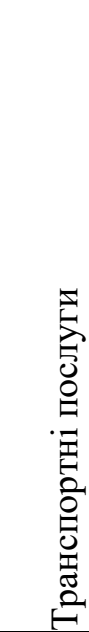 & 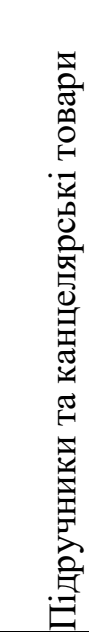 & 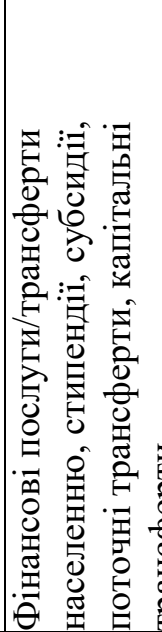 \\
\hline 1 & 2 & 3 & 4 & 5 & 6 & 7 & 8 & 9 & 10 & 11 & 12 \\
\hline Дошкільна освіта & 33,07 & 23,23 & 8,86 & 0,02 & 3,95 & 4,89 & 0,98 & 0,83 & 0,01 & & 0,14 \\
\hline Початкова освіта & 44,80 & 34,55 & 8,94 & 0,02 & 2,17 & 6,76 & 1,31 & 1,13 & 0,02 & 0,09 & 0,07 \\
\hline $\begin{array}{l}\text { Перший етап } \\
\text { середньої освіти }\end{array}$ & 47,88 & 36,93 & 9,56 & 0,02 & 2,32 & 7,22 & 1,40 & 1,20 & 0,02 & 0,09 & 0,08 \\
\hline
\end{tabular}




\begin{tabular}{|c|c|c|c|c|c|c|c|c|c|c|c|}
\hline \multicolumn{12}{|c|}{ Закінчення табл. 2} \\
\hline 1 & 2 & 3 & 4 & 5 & 6 & 7 & 8 & 9 & 10 & 11 & 12 \\
\hline $\begin{array}{l}\text { Другий етап } \\
\text { середньої освіти }\end{array}$ & 12,30 & 9,49 & 2,46 & 0,01 & 0,60 & 1,86 & 0,36 & 0,31 & 0,01 & 0,02 & 0,02 \\
\hline $\begin{array}{l}\text { Післясередня, не } \\
\text { вища освіта }\end{array}$ & 11,16 & 7,62 & 1,88 & 0,004 & 0,44 & 1,44 & 1,66 & 0,26 & 0,01 & 0,02 & 1,37 \\
\hline $\begin{array}{l}\text { Вища освіта (корот- } \\
\text { кий цикл, бакалаврат } \\
\text { або його еквівалент, } \\
\text { магістратура або їі } \\
\text { еквівалент) }\end{array}$ & 61,34 & 56,11 & 2,25 & 0,01 & 1,53 & 0,71 & 2,98 & 0,53 & 0,01 & 0,14 & 2,30 \\
\hline $\begin{array}{l}\text { Докторантура або iï } \\
\text { еквівалент }\end{array}$ & 3,45 & 3,20 & 0,13 & 0,0001 & 0,001 & 0,13 & 0,12 & 0,05 & 0,002 & & 0,06 \\
\hline Усього & 214,00 & 171,12 & 34,08 & 0,07 & 11,01 & 23,01 & 8,80 & 4,31 & 0,08 & 0,36 & 4,05 \\
\hline
\end{tabular}

1 Значення сумарних показників може не відповідати сумі часткових у зв'язку з переведенням одиниць вимірювання із тис. грн у млрд грн.

Джерело: [16].

Аналіз показників сателітного рахунку освіти в Україні за 2018 р. продовжимо розподілом витрат на освіту за провайдерами та функціями освіти на основі табл. 2.

Згідно неї, левову частку отриманих від фінансових агентів коштів, усі провайдери освіти витратили на послуги освіти, менші суми - на другорядну діяльність як у межах закладів освіти, так і пов’язану з навчанням. Зокрема, витрати провайдерів вищої освіти були такими:

- послуги у сфері освіти - 91,47\%;

- другорядна діяльність у межах закладів освіти - 3,67 \%,

У т. ч.: медичні послуги $-0,01 \%$;

послуги харчування $-2,50 \%$;

адміністративні послуги/комунальні, фінансові, відрядження, будівництво та ремонт (капітальні витрати) $-1,16 \%$;

- другорядна діяльність, що пов'язана $з$ навчанням - 4,85 \%,

у т. ч.: інвентар та обмундирування $-0,87 \%$;

транспортні послуги - 0,01\%;

підручники та канцелярські товари $-0,23 \%$;

фінансові послуги/трансферти населенню, стипендії, субсидії, поточні трансферти, капітальні трансферти - 3,75\%.

Відповідно до законодавства, джерелами фінансування суб'єктів освітньої діяльності можуть бути:

- державний бюджет;

- місцеві бюджети;

- плата за надання освітніх та інших послуг відповідно до укладених договорів;

- плата за науково-дослідні роботи (послуги) та інші роботи, виконані на замовлення

підприємств, установ, організацій, інших юридичних та фізичних осіб;

- доходи від реалізації продукції навчально-виробничих майстерень, підприємств, цехів і господарств, від надання в оренду приміщень, споруд, обладнання;

- гранти вітчизняних і міжнародних організацій;

- дивіденди від цінних паперів, відсотки від депозитів і розміщення коштів спеціального фонду на поточних рахунках банків державного сектору;

- добровільні внески у вигляді коштів, матеріальних цінностей, нематеріальних активів, одержаних від підприємств, установ, організацій, фізичних осіб;

- інші джерела, не заборонені законодавством [1].

Далі перейдемо до розробки механізму фінансово-інвестиційного забезпечення розвитку вищої освіти України в контексті функціонування ЄПВО, який міститиме фінансових агентів, інструменти та відповідні заходи на макро-, мезо- й мікрорівнях. Його відображено на рис. 2. 


\begin{tabular}{|c|c|c|c|c|}
\hline & Фінансові агенти & Інструменти & Заходи & $\begin{array}{l}\text { Інформаційно- } \\
\text { аналітичне } \\
\text { забезпечення } \\
\end{array}$ \\
\hline \multirow{9}{*}{$\begin{array}{l}\mathrm{P} \\
\mathrm{i} \\
\mathrm{B} \\
\mathrm{H} \\
\mathrm{i}\end{array}$} & \multicolumn{3}{|l|}{ МАКРОРІВЕНЬ } & \multirow{8}{*}{$\begin{array}{l}\text { Документи } \\
\text { ЄПВО: } \\
\text { - Хартія; } \\
\text { - Конвенція; } \\
\text { - Декларації; } \\
\text { - Звернення; } \\
\text { - Комюніке; } \\
\text { - Програма й ін. } \\
\text { Загально- } \\
\text { державні акти: } \\
\text { - Конституція } \\
\text { України; } \\
\text { - Кодекси } \\
\text { України; } \\
\text { - Закони } \\
\text { України; } \\
\text { - Укази } \\
\text { Президента } \\
\text { України й ін. } \\
\text { Документи у } \\
\text { сфері освіти та } \\
\text { науки: } \\
\text { - Постанови } \\
\text { КМУ; } \\
\text { - Накази МОН } \\
\text { України; } \\
\text { - Генеральна та } \\
\text { Галузева угоди; } \\
\text { - Статут } \\
\text { профспілки й ін. }\end{array}$} \\
\hline & $\begin{array}{l}\text { Центральний уряд: } \\
\text { - МОН України; } \\
\text { - МВС України; } \\
\text { - Міністерство } \\
\text { культури України; } \\
\text { - Міністерство } \\
\text { оборони України; } \\
\text { - Міністерство } \\
\text { охорони здоров'я } \\
\text { України; } \\
\text { - Міністерство } \\
\text { соціальної політики } \\
\text { України; } \\
\text { - Міністерство } \\
\text { аграрної політики та } \\
\text { продовольства } \\
\text { України; } \\
\text { - Міністерство } \\
\text { інфраструктури } \\
\text { України; } \\
\text { - Міністерство } \\
\text { фінансів України; } \\
\text { - Державна фіскальна } \\
\text { служба України; } \\
\text { - інші міністерства та } \\
\text { відомства. }\end{array}$ & $\begin{array}{l}\text { - держвитра- } \\
\text { ти на освіту як } \\
\text { \% від ВВП; } \\
\text { - структура та } \\
\text { суми видатків } \\
\text { на вищу } \\
\text { освіту; } \\
\text { - рівень } \\
\text { заробітної } \\
\text { плати } \\
\text { працівників } \\
\text { ЗВО; } \\
\text { - капітальні } \\
\text { інвестиції у } \\
\text { вищу освіту. }\end{array}$ & $\begin{array}{l}\text { - підвищення державних витрат на } \\
\text { освіту до } 7 \text { \% від ВВП; } \\
\text { - збільшення видатків держ-бюджету } \\
\text { на наукову і науково-технічну } \\
\text { діяльність ЗВО і наукових установ; } \\
\text { - підвищення рівня стимулюван-ня } \\
\text { науково-педагогічного персо-налу } \\
\text { ЗВО за рахунок збільшення видатків } \\
\text { на державні премії, стипендії та } \\
\text { гранти в галузі освіти, науки і } \\
\text { техніки; } \\
\text { - державне пільгове довгостро-кове } \\
\text { кредитування для здобуття вищої } \\
\text { освіти та кредитування будівництва } \\
\text { (придбання) житла для науково- } \\
\text { педагогічних і педагогічних } \\
\text { працівників; } \\
\text { - підвищення рівня заробітної плати } \\
\text { працівників ЗВО до середнього рівня } \\
\text { сусідніх європейських країн (710 } \\
\text { євро); } \\
\text { - створення сприятливого інвес- } \\
\text { тиційного клімату для залучення } \\
\text { капітальних інвестицій у вищу } \\
\text { освіту. }\end{array}$ & \\
\hline & \multicolumn{3}{|c|}{ Мета: перехід країни до економіки, заснованій на знаннях. } & \\
\hline & \multicolumn{3}{|l|}{ MEЗОРІВЕНЬ } & \\
\hline & $\begin{array}{l}\text { Обласні бюджети/ } \\
\text { Місцевий уряд }\end{array}$ & $\begin{array}{l}\text { - структура та } \\
\text { суми видатків } \\
\text { на ЗВО; } \\
\text { - капітальні } \\
\text { інвестиції у } \\
\text { ЗВО. }\end{array}$ & $\begin{array}{l}\text { - налагодження й активізація } \\
\text { співпраці органів місцевого } \\
\text { самоврядування із 3ВО з подальшим } \\
\text { фінансуванням; } \\
\text { - виконання спільних проектів (у т. ч. } \\
\text { міжнародних) на засадах } \\
\text { співфінансування. }\end{array}$ & \\
\hline & \multicolumn{3}{|c|}{ Мета: фінансово-інвестиційне забезпечення освітньо-наукового розвитку регіонів. } & \\
\hline & \multicolumn{3}{|l|}{ МIKРОРІВЕНЬ } & \\
\hline & $\begin{array}{l}\text { Недержавний сектор: } \\
\text { - приватні фірми та } \\
\text { корпорації (у т. ч. } \\
\text { закордонні); } \\
\text { - домашні } \\
\text { господарства. }\end{array}$ & $\begin{array}{l}\text { - структура та } \\
\text { суми видатків } \\
\text { на ЗВО; } \\
\text { - плата за } \\
\text { отримані } \\
\text { послуги, ро- } \\
\text { боти, товари; } \\
\text { - гранти; } \\
\text { - добровіль-ні } \\
\text { внески; } \\
\text { - капітальні } \\
\text { інвестиції у } \\
\text { ЗВО. } \\
\end{array}$ & $\begin{array}{l}\text { - збільшення плати за отримані } \\
\text { освітні й інші послуги; } \\
\text { - збільшення плати за науково- } \\
\text { дослідні роботи (послуги) та інші } \\
\text { роботи, виконані на замовлення; } \\
\text { - збільшення видатків на товари } \\
\text { 3ВО, оренду їх приміщень, споруд, } \\
\text { обладнання; } \\
\text { - збільшення грантів вітчизняних і } \\
\text { міжнародних організацій; } \\
\text { - надання добровільних внесків у } \\
\text { вигляді коштів, матеріальних } \\
\text { цінностей, нематеріальних активів. }\end{array}$ & \\
\hline & \multicolumn{3}{|c|}{ "Мета: збільшення фінансових надходжень для розвитку окремих ЗВО. } & \\
\hline
\end{tabular}

Рис. 2. Механізм фінансово-інвестиційного забезпечення розвитку вищої освіти Джерело: Власна розробка автора. 
Одним 3 інструментів сформованого механізму є структура та суми видатків на вищу освіту різних фінансових агентів, основним з яких є МОН. Водночас кожен ЗВО може надавати низку платних послуг, тим самим збільшуючи свої надходження, а відповідно й видатки

Зауважимо, що до документів ЄПВО нами віднесено такі: Велика хартія університетів (18.09.1988 р.); Лісабонська конвенція (11.04.1997 р.); Сорбонська декларація (25.05.1998 р.); Болонська декларація (19.06.1999 р.); Саламанське звернення (29-30.03.2001 р.); Празьке комюніке (19.05.2001 р.); Берлінське комюніке (19.09.2003 р.); Декларація Глазго (15.04.2005 р.); Бергенське комюніке (19-20.05.2005 р.); Лісабонська декларація (13.04.2007 р.); Лондонське комюніке (1718.05.2007 р.); Болонська робоча програма 2007-2009 (2-3.10.2007 p.); Льовенське комюніке (2829.04.2009 р.); Будапештсько-Віденська Декларація (10-12.03.2010 р.); Бухарестське комюніке (2627.04.2012 р.); Среванське комюніке (14-15.05.2015 р.); Паризьке комюніке (24-25.05.2018 р.).

Висновки і перспективи подальших досліджень. 3 огляду на сформований механізм, вважаємо доцільними такі рекомендації щодо вдосконалення фінансово-інвестиційного забезпечення розвитку вищої освіти:

1) щодо доходів:

а) диверсифікація джерел фінансування 3ВО із збільшенням частки залучених коштів обласних i місцевих бюджетів. Зокрема, ЗВО можуть запропонувати місцевій владі фінансування таких проєктів:

- проведення досліджень щодо історичної та культурної спадщини міста (регіону);

- формування туристичного іміджу й привабливості його культурно-історичних об'єктів;

- вивчення ресурсного потенціалу міста (регіону) та визначення пріоритетних напрямів його розвитку;

- проведення наукових досліджень і науково-технічних (експериментальних) розробок відповідно до визначених напрямів (зокрема, за тематикою МОН);

- стимулювання підприємницької діяльності та сприяння самозайнятості серед сільського й міського населення міста (області);

- проведення зимових і літніх шкіл із вузькоспеціалізованих наукових напрямів тощо;

- прогнозування показників розвитку міста (регіону);

б) активізація роботи з різноманітними фондами, центрами, грантодавцями та благодійниками. ЗВО повинні подавати заявки на фінансування держбюджетних тем у $\mathrm{MOH}$; брати участь у госпдоговірних темах, різноманітних освітніх і наукових проєктах (у тому числі міжнародних). Доречним буде подавання заявок на грантове фінансування;

в) пожвавлення власної інвестиційної діяльності. Це можна зробити за допомогою відкриття депозитних рахунків; створення навчально-науково-виробничих центрів, дослідних станцій, конструкторських бюро, навчально-виробничих комбінатів, експериментальних підприємств, університетських клінік і лікарень, юридичних клінік, наукових і технопарків тощо;

г) диверсифікація продукції (товарів, робіт, послуг). ЗВО доцільно розробляти та пропонувати нові види освітніх і наукових послуг, де споживачами можуть бути як фізичні, так і юридичні особи. Зокрема, жителям міста можна запропонувати різноманітні курси, семінари, тренінги, стажування, підвищення професійної компетентності:

- на мистецьких факультетах - бальних і сучасних танців, співу, образотворчого мистецтва;

- на природничих - ландшафтного дизайну, флористики;

- на економічних - управління персоналу, тім-білдінгу, тайм-менеджменту;

- на факультетах фізичної культури і здоров’я - фітнесу, аеробіки, шейпінгу, степ-аеробіки;

- на соціально-психологічних - проведення соціологічних досліджень, психологічні консультації тощо;

2) щодо видатків:

а) зниження в загальній сумі частки видатків споживання, які забезпечують поточне функціонування ЗВО. Зокрема встановити частку зарплат працівників ЗВО на рівні $57 \%$ від загальної суми видатків; зменшити оплату комунальних послуг та енергоносіїв за рахунок забезпечення енергоефективності усіх навчальних корпусів і гуртожитків ЗВО. Доречним буде подання заявок на участь у програмах з енергоощадності та енергоефективності; 
б) збільшення частки видатків розвитку на фінансове забезпечення наукової, інвестиційної та інноваційної діяльності ЗВО. Це можливо реалізувати за допомогою фінансового забезпечення капітальних вкладень виробничого i невиробничого призначення, зокрема будівництва та капремонту будівель; досліджень і розробок, окремих заходів із реалізації державних (регіональних) програм.

Перспективи подальших досліджень вбачаємо у розширенні заходів механізму фінансовоінвестиційного забезпечення розвитку вищої освіти України в контексті функціонування СПВО на макро-, мезо- й мікрорівнях.

\section{Джерела та література}

1. Про освіту Закон України від 05 верес. 2017 p. № 2145-VIII. URL: https://zakon.rada.gov.ua/laws/show/2145-19 (дата звернення: 01.09.2020).

2. Боголіб Т. М. Фінансове забезпечення розвитку вищої освіти і науки в Україні: автореф. дис. на здобуття наук. ступеня д-ра екон. наук: 08.04.01. Київ, 2006. 38 с.

3. Буцька О. Ю. Фінансове забезпечення діяльності вищого навчального закладу: автореф. дис. на здобуття наук. ступеня канд. екон. наук: 08.00.08. Донецьк, 2010. 18 с.

4. Ванієва М. Фінансовий механізм регулювання діяльності державних вищих навчальних закладів: автореф. дис. на здобуття наук. ступеня канд. екон. наук: 08.00.08. Львів, 2008. 20 с.

5. Гельман В. М. Фінансове забезпечення вищої освіти в Україні: автореф. дис. на здобуття наук. ступеня канд. екон. наук: 08.00.08. Донецьк, 2008. 20 с.

6. Гончаренко А. М. Управління капіталом приватного вищого навчального закладу: автореф. дис. на здобуття наук. ступеня канд. екон. наук: 08.00.04. Київ, 2009. 20 с.

7. Єрфорт О. Ю. Розвиток системи фінансового забезпечення вищої освіти в Україні: автореф. дис. на здобуття наук. ступеня канд. екон. наук. Київ, 2015. 22 с.

8. Іщук Л. І. Формування і використання фінансових ресурсів у вищих навчальних закладах: автореф. дис. на здобуття наук. ступеня канд. екон. наук: 08.00.08. Львів, 2010. 20 с.

9. Лев Т. О. Синтез системи фінансового менеджменту державного ВН3, що функціонує в умовах ринку: автореф. дис. на здобуття наук. ступеня канд. екон. наук: 08.06.02. Донецьк, 2000. 18 с.

10. Муравська В. А. Формування механізму фінансового забезпечення аграрної вищої освіти та науки в Україні: автореф. дис. на здобуття наук. ступеня канд. екон. наук. Київ, 2013. 21 с.

11. Олексин А. Г. Ефективність фінансування освітніх інновацій в системі вищої освіти України: автореф. дис. на здобуття наук. ступеня канд. екон. наук. Запоріжжя, 2012. 20 с.

12. Тимошенко О. В. Фінансовий механізм функціонування та розвитку системи вищої освіти в Україні: автореф. дис. на здобуття наук. ступеня канд. екон. наук: 08.00.08. Суми, 2010. 19 с.

13. Шашкевич О. Л. Фінансові ресурси вищих навчальних закладів: оптимізація формування та ефективність використання: автореф. дис. на здобуття наук. ступеня канд. екон. наук: 08.00.08. Тернопіль, 2008. $20 \mathrm{c}$.

14. Яришко О. В. Фінансове управління вищими навчальними закладами I-II рівня акредитації: автореф. дис. на здобуття наук. ступеня канд. екон. наук. Дніпропетровськ, 2006. 20 с.

15. Яструбський М. Я. Управління фінансовими ресурсами вищих навчальних закладів в умовах трансформації економіки України: автореф. дис. на здобуття наук. ступеня канд. екон. наук: 08.04.01. Львів, 2006. $20 \mathrm{c}$.

16. Сателітний рахунок освіти в Україні у 2018 році. Державна служба статистики України: вебсайт. URL: http://www.ukrstat.gov.ua (дата звернення: 31.03.2020).

\section{References}

1. Pro osvitu: Zakon Ukrainy vid 05 veres. 2017 r. № 2145-VIII [On education: Law of Ukraine from September 05 2017, № 2145-VIII]. Retrieved from https://zakon.rada.gov.ua/laws/show/2145-19 [in Ukrainian].

2. Boholib, T. M. (2006). Finansove zabezpechennia rozvytku vyshchoi osvity i nauky v Ukraini [Financial support for the development of higher education and science in Ukraine]. Kyiv [in Ukrainian].

3. Butska, O. Yu. (2010). Finansove zabezpechennia diialnosti vyshchoho navchalnoho zakladu [Financial support for the activities of a higher education institution]. Donetsk [in Ukrainian].

4. Vaniieva, M. (2008). Finansovyi mekhanizm rehuliuvannia diialnosti derzhavnykh vyshchykh navchalnykh zakladiv [Financial mechanism for regulating the activities of state higher education institutions]. Lviv [in Ukrainian].

5. Helman, V. M. (2008). Finansove zabezpechennia vyshchoi osvity v Ukraini [Financial support of higher education in Ukraine]. Donetsk [in Ukrainian]. 
6. Honcharenko, A. M. (2009). Upravlinnia kapitalom pryvatnoho vyshchoho navchalnoho zakladu [Capital management of a private higher education institution]. Kyiv [in Ukrainian].

7. Yerfort, O. Yu. (2015). Rozvytok systemy finansovoho zabezpechennia vyshchoi osvity v Ukraini [Development of the system of financial support of higher education in Ukraine]. Kyiv [in Ukrainian].

8. Ishchuk, L. I. (2010). Formuvannia i vykorystannia finansovykh resursiv u vyshchykh navchalnykh zakladakh [Formation and use of financial resources in higher educational institutions]. Lviv [in Ukrainian].

9. Lev, T. O. (2000). Syntez systemy finansovoho menedzhmentu derzhavnoho VNZ, shcho funktsionuie v umovakh rynku [Synthesis of the financial management system of a state HEI operating in market conditions]. Donetsk [in Ukrainian].

10. Muravska, V. A. (2013). Formuvannia mekhanizmu finansovoho zabezpechennia ahrarnoi vyshchoi osvity ta nauky $\mathrm{v}$ Ukraini [Formation of the mechanism of financial support of agrarian higher education and science in Ukraine]. Kyiv [in Ukrainian].

11. Oleksyn, A. H. (2012). Efektyvnist finansuvannia osvitnikh innovatsii v systemi vyshchoi osvity Ukrainy [Effectiveness of financing educational innovations in the system of higher education of Ukraine]. Zaporizhzhia [in Ukrainian].

12. Tymoshenko, O. V. (2010). Finansovyi mekhanizm funktsionuvannia ta rozvytku systemy vyshchoi osvity v Ukraini [Financial mechanism of functioning and development of the higher education system in Ukraine]. Sumy [in Ukrainian].

13. Shashkevych, O. L. (2008). Finansovi resursy vyshchykh navchalnykh zakladiv: optymizatsiia formuvannia ta efektyvnist vykorystannia [Financial resources of higher educational institutions: optimization of formation and efficiency of use]. Ternopil [in Ukrainian].

14. Yaryshko, O. V. (2006). Finansove upravlinnia vyshchymy navchalnymy zakladamy I-II rivnia akredytatsii [Financial management of higher educational institutions of I-II level of accreditation]. Dnipropetrovsk [in Ukrainian].

15. Yastrubskyi, M. Ya. (2006). Upravlinnia finansovymy resursamy vyshchykh navchalnykh zakladiv v umovakh transformatsii ekonomiky Ukrainy [Management of financial resources of higher educational institutions in the conditions of transformation of economy of Ukraine]. Lviv [in Ukrainian].

16. Derzhavna sluzhba statystyky Ukrainy [State Statistics Service of Ukraine]. Satelitnyi rakhunok osvity v Ukraini u 2018 rotsi [Satellite account of education in Ukraine in 2018]. (2020). Retrieved from http://www.ukrstat.gov.ua [in Ukrainian].

Стаття надійшла до редакції 02.09.2020 р. 